\title{
RELASI SUAMI ISTERI DALAM KONTEKS KELUARGA BURUH MIGRAN
}

\author{
Jamilah dan \\ Rasikh Adilla \\ Fakultas Syariah UIN Maulana Malik Ibrahim Malang
}

\begin{abstract}
Abstrak
This research aims at analyzing spouse relation construction among migrant worker families in Patok Picis Village, Wajak, Malang with wives as the additional bread winner. This research is descriptive empirical research by applying qualitative method on spouse relationship phenomenon in migrant workers family context. Deep interview technique is used to collect data through interview with migrant workers worker' husbands. The results of this research reveal three main findings; 1) the relation is mainly determined by the ability of wife and husband to be main and additional breadwinner. 2) the relation which is build is not based on justice and equity principle and it tends to be subordination after the wife ends the contract. 3) Husband states that the relation socially which must be built in the family must put husband's position higher than wife's.

Penelitian ini bertujuan untuk mengkaji konstruksi relasi suami istri yang dibangun oleh keluarga buruh migran di desa Patok Picis kecamatan Wajak Kabupaten Malang dengan kondisi istri yang bekerja sebagai pencari nafkah tambahan. Penelitian ini merupakan penelitian empirik yang bersifat deskriftif terhadap fenomena relasi suami istri dalam konteks keluarga buruh migran. Teknik wawancara secara mendalam digunakan untuk mengumpulkan data melalui wawancara dengan suami buruh migran. Hasil penelitian menyimpulkan antara lain; 1) relasi yang dibangun sangat ditentukan oleh kemampuan suami atau istri dalam mencari nafkah utama dan tambahan.2) relasi yang dibangun tidak berdasarkan prinsip keadilan dan kesetaraan akan tetapi cenderung subordinasi ketika istri selesai menjadi buruh migrant. 3) Suami berpendapat bahwa secara social, relasi yang harus dibentuk dalam keluarga adalah kedudukan suami lebih tinggi dari istri.
\end{abstract}

Kata Kunci: Relasi, Kepala Keluarga, Buruh Migran

Konsep relasi suami dan isteri adalah salah satu aspek yang telah diatur dalam Islam sebagaimana yang tercantum dalam al-Qur'an dan hadits sebagai sumber utama dari dibentuknya hukum Islam. Nilai-nilai yang terkandung pada relasi yang dibentuk berasaskan keadilan, kasih sayang dan kesetaraan yang bertujuan untuk pembentukan keluarga sakinah mawaddah wa rahmah. Secara teoritis dan konseptual, masalah relasi suami dan isteri tentu tidak terdapat persoalan. Akan tetapi, dalam tataran implementatif, seringkali masalah relasi suami isteri mendapat persoalan secara teknis dilapangan karena permasalahan nilai, budaya, sosial, ekonomi dan hukum positif yang melingkupinya. Hal ini juga terjadi pada keluarga buruh migran dengan isteri sebagai pencari nafkah utama dan tambahan bagi keluarga.

Dalam sebuah keluarga, secara fungsional, 
terdapat sebuah peran yang disebut sebagai kepala keluarga. Kepala keluarga adalah orang yang bertanggung jawab terhadap suatu keluarga (biasanya bapak). ${ }^{1}$ Peran kepala keluarga tersebut akan berdampak pada pola relasi yang akan dibangun oleh masing-masing keluarga berdasarkan kesepakatan bersama antara suami atau isteri. Dalam mengkaji relasi suami-isteri dalam konteks rumah tangga, penelitian ini menggunakan teori kedudukan kepala rumah tangga yang diberikan kepada salah satu jenis kelamin atau pihak suami atau isteri berdasarkan tinjauan fikih dan Hukum positif yang tercantum dalam UU pernikahan tahun 1974. Konsep kepala keluarga yang digunakan sebagai rujukan dalam fikih mengacu kepada surat al-Nisa' ayat 35 yang kemudian menimbulkan berbagai penafsiran secara konseptual dan teknis implementatif oleh beberapa pemikir muslim seperti Ar-Razi dan Ali Asgahar engineer.

Dari kedua konsep tentang kepala keluarga yang tercantum dalam sumber hukum Islam dan hukum positif Indonesia tersebut, maka relasi yang harus dibangun adalah bersifat hirarki dengan menempatkan suami melebihi isteri meskipun masih terdapat argumenargumen fikih kontemporer terkait kedudukan suami dan isteri serta relasi yang harus dibangun jika dikaitkan dengan peran dan fungsi suami dalam keluarga. Berdasarkan uraian dan paparan argumentasi tersebut, maka penelitian ini berupaya untuk mengkaji pola relasi yang dibentuk oleh suami dan isteri di lingkungan keluarga buruh migran baik sebelum maupun sesudah isteri bekerja menjadi buruh migran.

\section{METODE PENELITIAN}

Jenis penelitian ini adalah penelitian empiris karena penelitian ini bermaksud untuk menganalisa data lapangan yang diperoleh dari pengambilan data konstruk relasi yang dibangun antara suami dan isteri dikalangan keluarga buruh migran. Penelitian ini menggunakan dua paradigma penelitian

\footnotetext{
${ }^{1}$ Departemen Pendidikan dan Kebudayaan, Kamus Besar Bahasa Indonesia, (Jakarta: Balai Pustaka, 1997), h.480.
}

dalam menganalisa data. Paradigma pertama, penelitian ini akan menggunakan paradigma naturalistik (naturalistic paradigm). Paradigma ini didasarkan pada pandangan fenomenologis yang diusung oleh Max Weber dan Irwin Deuthcer. Paradigma ini digunakan untuk memahami perilaku suami dan isteri dalam membangun relasi dari aspek kerangka pikir maupun tindakan dari suami isteri dan hal-hal yang melingkupi orang-orang yang terlibat dalam keluarga. Paradigma kedua, penelitian ini juga menggunakan paradigma hukum Islam (fikih) untuk mengkaji dan menganalisa konsep atau konstruk relasi yang dibangun oleh suami dan isteri dari keluarga buruh migran.

Pendekatan yang digunakan dalam penelitian ini adalah pendekatan kualitatif deskriptif. Pendekatan ini digunakan untuk melihat satuansatuan gejala dalam kehidupan masyarakat yaitu masyarakat di lokasi penelitian dengan gejala sosial yang permissive pada segala dampak yang dihasilkan dari fenomena buruh migran serta dampaknya bagi relasi suami isteri dalam sebuah keluarga. Melalui pendekatan ini, diharapkan penelitian ini dapat memaparkan data-data yang menggambarkan pola pikir dari suami dan isteri yang dikonstruk oleh kebudayaan yang melingkupinya serta faktorfaktor yang muncul dari dalam diri suami dan isteri sendiri. Dalam mengumpulkan data, teknik pengumpulan data yang dilakukan salah satunya dengan cara wawancara atau observasi yang memungkinkan peneliti melakukan observasi partisipatif (participatory observation). ${ }^{2}$ Pendekatan ini digunakan karena subjek penelitian berupa gejala proses yang lebih mudah dijelaskan dengan deskripsi kata-kata yaitu suami dan isteri yang berprofesi sebagai buruh migran dengan landasan pemenuhan ekonomi keluarga.

\section{HASIL PENELITIAN DAN PEMBAHASAN}

Pada dasarnya, pilihan bekerja menjadi buruh migran bagi sebuah keluarga merupakan persoalan yang mengancam bagi ketahanan keluarga karena beberapa permasalahan yang

${ }^{2}$ Hadari Nawawi, Metodologi Penelitian Bidang Sosial (Yogyakarta: Gajahmada University Press, 1995), h. 79 
akan dihadapi dikemudian hari sebagaimana berikut; (1) Rawan terjadinya perceraian; (2) Rawan terjadinya perselingkuhan; (3) Pembagian peran suami dan isteri yang tidak berimbang dan tidak berjalan; (4) Pendidikan keluarga yang terabaikan terkait dengan peran orang tua sebagai pendidik anak; (5) Persoalan kewajiban menacari nafkah yang bergeser dan berdampak pada relasi suami isteri yang dibangun; (6) Hak dan proses pengambilan keputusan; (7) Izin suami untuk menjadi tenaga kerja wanita, jika yang menjadi buruh migran adalah isteri. Persoalan-persoalan tersebut adalah beberapa persoalan yang akan dihadapi oleh keluarga buruh migran. Salah satu permasalahan yang sangat rentan akan muncul adalah relasi suami isteri yang akan sangat bervariasi dan berubah ketika suami atau isteri yang menjadi buruh migran pulang dari luar negeri. Relasi yang sudah dibentuk pada awal pernikahan akan memungkinkan berubah atau dibentuk ulang berdasarkan kesepakatan-kesepakatan baru terutama tentang posisi suami dan isteri dalam konteks penentu berbagai keputusan yang akan diambil bagi keluarga.

Persoalan yang dihadapi oleh keluarga buruh migran juga dialami oleh masyarakat Desa Patokpicis, Kecamatan Wajak, Kabupaten Malang. Sebagian masyarakat saat ini (saat penelitian dilakukan) memilih menjadi buruh migran terutama kalangan perempuan atau isteri. Pada awalnya pilihan menjadi buruh migran bukan pilihan utama untuk menyelesaikan persoalan ekonomi karena mata pencaharian utama masyarakat sebagai petani sudah cukup memadai dalam konteks kebutuhan masyarakat Desa. Akan tetapi, keberhasilan beberapa orang diantara masyarakat Desa menjadi tenaga kerja wanita di luar negeri menajdi daya tarik bagi perempuan lainnya terutama bagi mereka yang sudah berkeluarga dengan alasan menambah penghasilan keluarga dan mengusahakan kehidupan yang lebih layak lagi, seperti memiliki rumah mewah, perhiasan dan gaya hidup modern dengan berbagai perlengkapan elektronik dan fasilitas lainnya termasuk gaya hidup. Dengan pilihan kerja tersebut, terjadi beberapa perubahan sosial dalam masyarakat terutama dalam konteks kehidupan keluarga dikalangan pekerja tersebut yang bersumber dari local wisdom setempat dan ajaran agama tentang bagaimana relasi yang berkeadilan dan setara anatara laki-laki dan perempuan sebagai suami dan isteri. Tidak hanya masalah relasi suami isteri, banyak persoalan lain yang dihadapi oleh masyarakat Desa Patokpicis dengan menjadi buruh migran, seperti terjadinya praktek poliandri, pengindahan terhadap suami, pendidikan formal, agama dan sosial anak yang terabaikan, serta perceraian.

Jika kita merujuk pada konsep kepala keluarga dalam Islam yang tertera pada surat An Nisa' ayat 35 yang berarti: "Laki-laki itu adalah pemimpin bagi kaum wanita, oleh karena Allah telah melebihkan sebahagian mereka (laki-laki) atas sebahagian yang lain (wanita), dan karena mereka (laki-laki) telah menafkahkan sebagian dari harta mereka. sebab itu Maka wanita yang saleh, ialah yang taat kepada Allah lagi memelihara diri ketika suaminya tidak ada, oleh karena Allah telah memelihara (mereka). wanita-wanita yang kamu khawatirkan nusyuznya, Maka nasehatilah mereka dan pisahkanlah mereka di tempat tidur mereka, dan pukullah mereka. kemudian jika mereka mentaatimu, Maka janganlah kamu mencari-cari jalan untuk menyusahkannya. Sesungguhnya Allah Maha Tinggi lagi Maha besar.

Maka pada dasarnya masyarakat Patokpicis mengakui hal tersebut, dengan meletakkan posisi laki-laki sebagai kepala keluarga ketika suami dan isteri tidak bekerja menjadi buruh migran. Gambaran umum di lapangan menyatakan bahwa pada umumnya suami akan berperan dalam ranah domestik dan publik ketika isteri masih menetap di rumah dan tidak bekerja sebagai buruh migran. Ini artinya, isteri sangat bergantung pada suami terkait nafkah. Akan tetapi ketika terjadi perubahan dalam pemenuhan nafkah keluarga, maka akan terjadi perubahan. Peran suami sebagai kepala keluarga hanya pada ranah eksternal keluarga atau di ranah publik. Kondisi ini dapat kita rujukkan pada konsep kepala keluarga berdasarkan pemikiran ar-Razi. 
Menurut ar Razi, salah satu keutamaan lakilaki atas perempuan adalah Shifat haqiqiyyahnya yang mengacu pada dua hal, yaitu : pengetahuan dan kemampuan. Menurut ar Razi, keunggulan laki-laki atas perempuan dalam hal pengetahuan dan kemampuan untuk bekerja tidak dapat diragukan lagi. ${ }^{3}$ Hal ini menjadi sebab pertama mengapa laki-laki menjadi pemimpin. Penyebab kedua adalah nafkah yang diberikan laki-laki kepada perempuan. Hal ini karena adanya kewajiban bagi laki-laki untuk memberikan mahar pada wanita dan memberinya nafkah. ${ }^{4}$ Ar Razi juga mencantumkan sabab nuzul ayat ini, yaitu :

$$
\begin{aligned}
& \text { قال ابن عباس : نزلت هذه الآية في بنت محمد بن سلمة }
\end{aligned}
$$

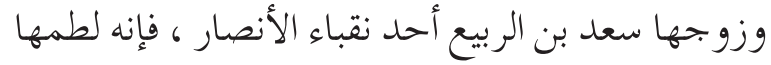

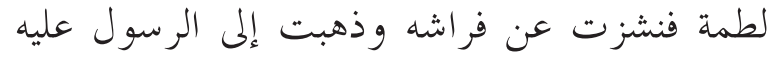

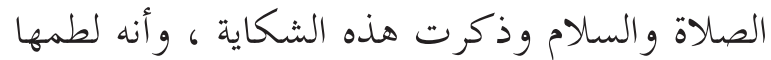

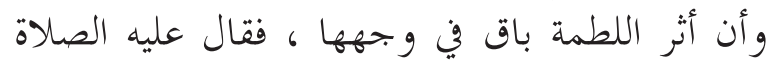

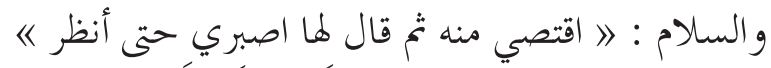

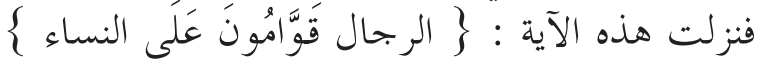

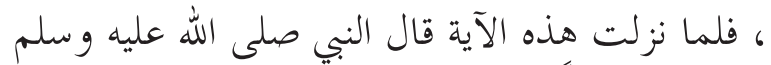

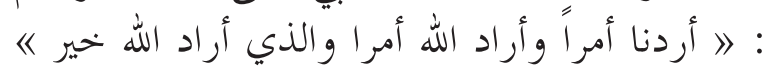

$$
\begin{aligned}
& \text { ورفع القصاص إدنا أو }
\end{aligned}
$$

"Ibnu 'Abbas berkata : ayat ini turun pada anak perempuan Muhammad bin Salamah dan suaminya Sa'd bin ar Rabi', salah seorang pemimpin kaum Anshar. Sa'd bin ar Rabi' telah memukul anak perempuan Muhammad bin Salamah kemudian ia (anak perempuan Muhammad bin Salamah) nusyuz dari kasurnya kemudian pergi bertemu Rasul SAW dan mengadu bahwasanya (suaminya) telah memukulnya bahkan bekasnya masih tersisa di wajahnya. Kemudian Rasulullah bersabda, "menjauhlah darinya, bersabarlah hingga aku pertimbangkan." Lalu turun ayat ini : الرجال قَوَّامُون

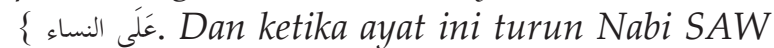
bersabda, "Aku menginginkan suatu perkara, dan Allah menginginkan perkara lain. Maka yang diinginkan Allah lah yang terbaik."

\footnotetext{
${ }^{3} \mathrm{Abu}$ 'Abdillah Muhammad bin 'Umar bin al Hasan bin al Husain at Taimi Ar Razi, Tafsir al Fakhri li al Maktabah asy Syamilah, (Mauqi' at Tafsir), h. 192.

${ }^{4}$ Ibid.

${ }^{5}$ Ibid.
}

Sabda Rasulullah SAW "Aku menginginkan suatu perkara, dan Allah menginginkan perkara lain. Maka yang diinginkan Allah lah yang terbaik" setelah ayat tersebut turun, menurut ar Razi merupakan informasi bahwa kepemimpinan laki-laki itu merupakan kehendak Allah SWT. Konsepsi tersebut diperkuat dengan hadits Rasul SAW yang diriwayatkan oleh Bukhari dan Muslim:

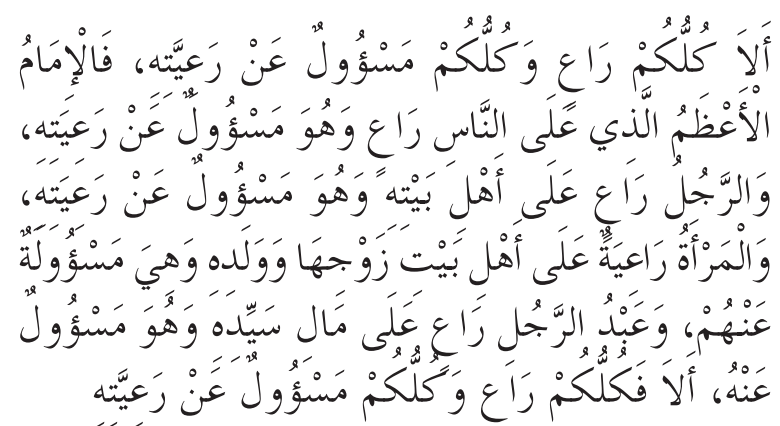

“Śtiap kalian adalah ra'in dän setiap kalian akan ditanya tentang ra'iyahnya. Imam a'zham (pemimpin negara) yang berkuasa atas manusia adalah ra'in dan ia akan ditanya tentang ra'iyahnya. Seorang lelaki/suami adalah ra' in bagi ahli bait (keluarga)nya dan ia akan ditanya tentang ra'iyahnya. Wanital isteri adalah ra'iyah terhadap ahli bait suaminya dan anak suaminya dan ia akan ditanya tentang mereka. Budak seseorang adalah ra'in terhadap harta tuannya dan ia akan ditanya tentang harta tersebut. Ketahuilah setiap kalian adalah ra'in dan setiap kalian akan ditanya tentang ra'iyahnya."

Konsepsi yang ditawarkan oleh Ar-razi tersebut dapat kita lihat di lokasi penelitian. Ketika suami yang pada awalnya diposisikan sebagai kepala keluarga dengan kedua kelebihannya tersebut tidak terpenuhi keduanya, maka kedudukan tersebut dapat bergeser dan membentuk pola relasi baru dengan dua kondisi. Kondisi pertama, ketika suami memiliki pengetahuan yang lebih dari apa yang dimiliki isteri, maka kelebihan tersebut tidak menjadi catatan bagi isteri untuk menyepakati secara mudah bahwa suami adalah kepala keluarga. Alasan tersebut tidak muncul selama wawancara untuk dijadikan landasan seseorang untuk menjadi kepala keluarga. Jika isteri menempatkan suami sebagai keluarga, maka hal tersebut semata-mata hanya karena konstruk sosial yang telah ada di lingkungan mereka pada 
umumnya. Kondisi kedua, jika kemampuan dan kelebihan laki-laki dalam memberi nafkah adalah salah satu alasan untuk menempatkannya sebagai kepala keluarga, maka para suami di patokpicis mendapatkan posisi tersebut pada umumnya tidak hanya berbasis pada kemampuan dia memeberi nafkah akan tetapi dia secara otomatis menjadi kepala keluarga meskipun isteri menjadi pencari nafkah utama atau tambahan.

Berbeda dengan ar Razi, Asghar Ali Engineer berpendapat bahwa keunggulan laki-laki atas perempuan tidak berupa keunggulan jenis kelamin, melainkan keunggulan fungsional, karena laki-laki mencari nafkah dan membelanjakannya untuk perempuan (fungsi sosial) sedangkan perempuan menjalankan fungsi domestik. Menurutnya, fungsi sosial yang diemban lakilaki pada masa itu sesungguhnya seimbang dengan fungsi domestik yang diemban oleh perempuan. Sehingga, bisa jadi kewajiban memberi nafkah bagi laki-laki pada masa itu dapat diartikan sebagai penyeimbang peran domestik yang dilakukan oleh perempuan. Hal ini harus dipahami demikian, karena menurutnya ayat ini tidak boleh dipahami lepas dari konteks sosial pada saat ayat ini diturunkan. Pada masa Nabi tidaklah mengakui kesetaraan antara laki-laki dan perempuan. Oleh karena itu, tidak boleh mengambil pandangan yang semata-mata bersifat teologis, tetapi harus menggunakan pandangan sosio-teologis. ${ }^{6}$

Sedangkan Wahbah az Zuhaili memandang bahwa ayat ini menunjuk Kepala Keluarga dan hal-hal mengenai penentuan pemimpin/ kepala keluarga sebagai berikut: (a) Ayat ini menunjuk laki-laki sebagai pemimpin/kepala keluarga; (b) Ketidak mampuan laki-laki dalam menafkahi membuat kepemimpinan laki-laki itu hilang.7 Pendapat Ali Engineer dan Wahbah Zuhaili nampaknya tidak berlaku pada sebagian besar penduduk Patokpicis, karena para suami mengangaggap bahwa pilihan isteri menjadi buruh migran karena persetujuan bersama

\footnotetext{
${ }^{6}$ Asghar Ali Engineer, Hak-Hak Perempuan dalam Islam, (Yogyakarta: Yayasan Bentang Budaya, 1994), h. 61.

${ }^{7}$ Wahbah bin Musthafa az Zuhaili, At Tafsir al Munir $f_{i}$ al 'Aqidah wa asy Syari'ah, (Damaskus: Daar al Fikr, 1418 H), h. 60 .
}

dan suami sudah berusaha menafkahi dengan kadar kemampuannya.

Hasil paparan data yang diperoleh melalui wawancara dengan informan terkait kedudukan kepala keluarga mengindikasikan pemahaman dan konsep yang dimiliki oleh para informan tentang kepala keluarga berpacu pada satu kondisi saja, yaitu kedudukan kepala keluarga selamanya ada di pihak suami. Para Informan memandang bahwa kedudukan suami sebagai kepala keluarga adalah pada konteks sosial, domestik, dan agama sehingga kedudukan tersebut tidak dapat digantikan oleh isteri. Dengan demikian, relasi yang dibangun tidak lah berkesetaraan dan berkeadilan gender. Hal ini ditunjukkan oleh data lapangan yang menggambarkan bahwa isteri harus tetap patuh dan melakukan apapun berdasarkan izin suami dan kesepakatan bersama. Salah satu kasus menunjukkan bahwa isteri harus menurut dengan suami dalam berbagai hal seperti tuntutan pemenuhan nafkah batin dari isteri terhadap suami. Ketika isteri tidak mampu melakukannya karena berada jauh dari suami, maka isteri harus memenuhinya meskipun dengan cara mengijinkan suami berzina dengan orang lain dengan biaya yang diberikan oleh isteri sebagi bentuk dari ketaatan seorang isteri kepada suami dan sebagai bentuk kompensasi dari kewajiban yang tidak dapat dipenuhi.

Posisi demikian tetap berlaku meskipun peran kepala keluarga sudah berpindah kepada isteri, misalnya suami yang tidak dapat memenuhi kebutuhan keluarga, sehingga isteri bekerja dengan pendapatan melebihi pendapatan suami, maka tidak secara otomatis kedudukan kepala keluarga berpindah kepada isteri, melainkan kedudukan kepala keluarga tersebut tetap berada pada suami meskipun peran kepala keluarga tersebut dibagi dengan isteri. Pendapat tersebut dapat kita lihat dari pernyataan informan I (Bapak Hadi) yang menyatakan: "Masalah nafkah dan kebutuhan keluarga sebenarnya kewajiban suami, kita sudah faham itu, semua masyarakat disini ya sepakat, tapi kalau kondisi tidak sesuai dan ternyata istri yang mampu, ya kan itu untuk kebutuhan keluarga 
bersama-sama, ya tidak apa-apa istrinya kerja.tapi kalau dalam rumah tangga, suami tetap kepala keluarga.Masa' hanya karena gitu kita ga jadi kepala keluarga." Pendapat tersebut menguatkan pemahaman tentang kedudukan suami berbeda dengan peran suami dalam keluarga yaitu kedudukan kepala keluarga bersifat prestige yang tidak dapat bergeser meskipun perannya dapat berubah atau berbagi dengan istri seperti peran mencari nafkah untuk keluarga.

Selanjutnya, Jika kita membahas tentang konsep kepala keluarga dalam Peraturan Perundang - undangan Indonesia pasti mengacu pada UU nomor 1 tahun 1974 tentang perkawinan yang selanjutnya disebut UU Perkawinan. Konsep kepala keluarga pada UU Perkawinan dapat dilihat pada pasal 31. Pada pasal 31 tersebut, dinyatakan bahwa hak dan kedudukan isteri adalah seimbang dengan hak dan kedudukan suami dalam kehidupan rumah tangga dan pergaulan hidup bersama dalam masyarakat. Hal ini berimplikasi pada posisi mereka dalam keluarga yaitu masing-masing pihak berhak untuk melakukan perbuatan hukum. Pasal tersebut juga menyatakan dengan tegas bahwa suami adalah kepala keluarga dan isteri ibu rumah tangga.

Pasal 31 ayat 3 UU Perkawinan memang secara tegas menyebutkan posisi suami sebagai kepala keluarga dan isteri sebagai ibu rumah tangga. Meski demikian, UU Perkawinan belum menyebutkan secara tegas tanggungjawab suami dalam menjalankan posisinya sebagai kepala keluarga. UU Perkawinan hanya menjelaskan secara umum tanggung jawab suami - isteri tersebut pada Pasal 34. Pasal ini menjelaskan hak dan kewajiban masing-masing pihak baik suami maupun isteri. Pasal ini secara tidak langsung mengkonstruk pemahaman masyarakat terhadap pembentukan relasi dalam sebuah keluarga. Misalnya saja, suami wajib melindungi isterinya dan memberikan segala sesuatu keperluan hidup berumah tangga sesuai dengan kemampuannya, isteri wajib mengatur urusan rumah-tangga sebaikbaiknya dan jika suami atau isteri melalaikan kewajibannya masing-masing dapat mengajukan gugatan kepada Pengadilan. Rincian dari pasal tersebut nampak tidak berlaku di masyarakat desa Patokpicis secara detail, akan tetapi hal tersebut hanya menjadi garis besar pedoman bagi sebuah keluarga dengan mengakui kedudukan masing-masing. Meskipun, terdapat 1-2 pasangan yang tidak menerapkan secara tekstual pasal tersebut.

Situasi ini berbeda dengan figh Islamy yang memberikan penjelasan secara terperinci mengenai kewajiban suami melaksanakan posisi sebagai kepala keluarga yang kemudian diadopsi ke dalam Inpres No. 1 Tahun 1991 tentang Kompilasi Hukum Islam yang selanjutnya disebut KHI sebagaimana disebutkan pada Pasal 80, yaitu (1) Suami adalah pembimbing, terhadap isteri dan rumah tangganya, akan tetapi mengenai hal-hal urusan rumah tangga yang penting-penting diputuskan oleh sumai isteri bersama; (2) Suami wajib melidungi isterinya dan memberikan segala sesuatu keperluan hidup berumah tangga sesuai dengan kemampuannya; (3) Suami wajib memberikan pendidikan agama kepada isterinya dan memberi kesempatan belajar pengetahuan yang berguna dan bermanfaat bagi agama, nusa dan bangsa; (4) Sesuai dengan penghasilannya suami menanggung nafkah, kiswah dan tempat kediaman bagi isteri, biaya rumah tangga, biaya perawatan dan biaya pengobatan bagi isteri dan anak dan biaya pendidikan bagi anak. (5) Kewajiban suami terhadap isterinya seperti tersebut pada ayat (4) huruf a dan b di atas mulai berlaku sesudah ada tamkin sempurna dari isterinya.5) Isteri dapat membebaskan suaminya dari kewajiban terhadap dirinya sebagaimana tersebut pada ayat (4) huruf a dan b; (6) Kewajiban suami sebagaimana dimaksud ayat (5) gugur apabila isteri nusyuz.

Dari keseluruhan poin tersebut diatas, poin penting yang dijadikan landasan bagi suami atau isteri di Desa Patokpicis hanyalah persoalan nafkah. Data yang diperoleh dari wancara menunjukkan bahwa terdapat konstruk relasi suami dan isteri yang mengarah pada konsep yang ditawarkan oleh para pemikir hukum Islam kontemporer, yaitu terdapat kemungkinan bagi berubahnya status dan 
kedudukan suami sebagi kepala keluarga dan hal tersebut berdampak pada relasi yang akan dibangun oleh suami isteri. Masyarakat desa Patokpicis pada awalnya adalah masyarakat yang memiliki sosial sistem sebagaimana masyarakat Jawa pada umumnya yang mengatur relasi suami isteri dalam sebuah keluarga yaitu menempatkan suami dan isteri dalam bentuk hirarki yang menempatkan suami lebih tinggi dari isteri melalui peran sebagi kepala keluarga. Hal ini berlaku hingga isteri belum berangkat menjadi buruh migran.

Konsep tentang kedudukan dan peran kepala keluarga sangat bervariasi bagi suami dari perempuan yang bekerja sebagai buruh migran di Desa Patokpicis. Konsep yang mereka miliki dibentuk dari pemahaman yang berbasis sosial religious meskipun yang mereka pahami dari sumber-sumber agama tidak cukup mendalam. Pada umumnya, para informan memiliki pemahaman yang sama tentang relasi yang harus dibangun yaitu simbol dari relasi yang dibentuk adalah dengan menempatkan salah satunya pada kedudukan kepala keluarga dengan menempatkan suami pada posisi yang tidak tergeserkan atau tergantikan dalam situasi dan kondisi apapun. Posisi demikian tetap berlaku meskipun peran kepala keluarga sudah berpindah kepada isteri, misalnya suami yang tidak dapat memenuhi kebutuhan keluarga, sehingga isteri bekerja dengan pendapatan melebihi pendapatan suami, maka tidak secara otomatis kedudukan kepala keluarga berpindah kepada isteri, melainkan kedudukan kepala keluarga tersebut tetap berada pada suami meskipun peran kepala keluarga tersebut dibagi dengan isteri. Akan tetapi, masing-masing informan memiliki perbedaan dalam tataran implementasi dari konsep kedudukan kepala keluarga serta peran yang harus dijalankan sebagai konsekuensi dari peran kepala keluarga dan implementasi praktisnya. Akan tetapi, ketika keputusan pemenuhan nafkah keluarga adalah melalui bekerja sebagai buruh migran keluar negeri. Relasi suami dan isteri dapat berubah baik melalui persetujuan kedua belah pihak maupun tidak.
Hasil paparan data terkait dengan kedudukan kepala keluarga mengindikasikan pemahaman dan konsep yang dimiliki oleh para informan tentang kepala keluarga mengacu pada satu kondisi saja, yaitu kedudukan kepala keluarga selamanya ada di pihak suami. Para Informan memandang bahwa kedudukan suami sebagai kepala keluarga adalah pada konteks sosial, domestik, dan agama sehingga kedudukan tersebut tidak dapat digantikan oleh isteri. Dalam tataran implementasi, terdapat beberapa pasangan suami isteri yang menerapkan nilai kesetaraan dan keadilan bagi suami dan isteri dengan tidak menempatkan salah satunya lebih tinggi dari yang lain.

Pada suatu penelitian, ada keluarga informan dengan kondisi isteri sebagai pencari nafkah tambahan dalam keluarga yaitu dengan bekerja sebagai buruh migran di luar negeri. Keputusan yang diambil adalah berdasarkan musyawarah antara kedua belah pihak, isteri dan suami. Ketika isteri berangkat dan bekerja di luar negeri, suami mengelola semua hasil kerja isteri yang didapat dari gaji. Kemudian ketika kontrak kerja berakhir, isteri kemudian kembali kepada suami dan keluarga, isteri tidak merasa lebih superior dari suami hanya karena melakukan peran sebagai pencari nafkah tambahan.menurut informan, kemampuan salah satu dari suami atau isteri tidak harus merubah kedudukan suami atau isteri sebelumnya karena apa yang dilakukan oleh salah satu mereka adalah berdasarkan kesepakatan dan persetujuan untuk kemaslahatan keluarga. Adapun status sosial yang dibentuk oleh masyarakat terhadap suami untuk menjadi kepala keluarga bukan berimplikasi pada superioritas seseorang terhadap orang lain terutama pasangan hidup dalam konteks keluarga.

Adapun bentuk lain dari relasi yang dibangun dalam keluarga buruh migran adalah sangat ditentukan oleh kemampuan suami atau isteri dalam mencari nafkah utama dan tambahan. Salah satu keluarga informan mengalami perubahan relasi suami dan isteri akibat dari pilihan isteri menjad buruh migran dan melakukan pemenuhan nafkah keluarga. 
Hal ini berpengaruh pada relasi informan dengan isterinya. Isteri yang awalnya selalu ditekan dengan keputusan - keputusan yang diambil oleh suami secara sepihak, menjadi isteri yang ingin mendominasi seluruh aspek keluarga khususnya dalam hal pengambilan keputusan setelah isteri tersebut selesai bekerja di luar negeri dan memiliki harta yang lebih banyak dari Informan. Walaupun selama isteri tersebut menjadi buruh migran Informan selalu menjaga hasil dari pekerjaan yang dilakukan oleh isterinya. Isteri merasa lebih superior dari suami dan menganggap bahwa posisi suami adalah subordinat dengan dasar nafkah dipenuhi oleh isteri.

\section{KESIMPULAN}

Berdasarkan hasil penelitian dan pembahasan, kesimpulan yang diperoleh dari penelitian ini adalah (1) Para informan memiliki pemahaman atau konsep sama tentang relasi yang dibangun bagi suami dan isteri adalah menempatkan salah satu dari keduanya sebagai kepala keluarga dan membebankan tangungjawab kepada seorang kepala keluarga untuk memenuhi nafkah, melakukan peran pendidikan atau mendidik anggota keluarga.

\section{DAFTAR PUSTAKA}

Ar Razi, Abu 'Abdillah Muhammad bin 'Umar bin al Hasan bin al Husain at Taimi, Tafsir al Fakhri li al Maktabah asy Syamilah, Mauqi' at Tafsir.

Ibn Katsir, Abu al Fida' Isma'il bin Umar, Tafsir al Qur'an al 'Adhim li al Maktabah asy Syamilah, Damaskus : Dar ath Thayyibah li an Nasyri wa at Tauzi'.

Engineer, Asghar Ali, Hak-Hak Perempuan dalam Islam, Yogyakarta: Yayasan Bentang Budaya, 1994.

Buletin Islam AL ILMU Edisi: 13/IV/IX/1432

Ashsofa, Burhan, Metode Penelitian Hukum. Jakarta: Rineka Cipta, 1998.

Departemen Pendidikan dan Kebudayaan, Kamus Besar Bahasa Indonesia, Jakarta:
Peran-peran tersebut ketika mampu dilakukan oleh salah seorang dari suami atau isteri akan berimplikasi pada hak ayang akan diperoleh oleh seorang kepala keluarga seperti hak sebagai pengambil keputusan yang pada umumnya bersifat urusan domestik atau internal keluarga; (2) Relasi yang dibangun tidak berdasarkan prinsip keadilan dan kesetaraan akan tetapi cenderung subordinasi ketika isteri selesai menjadi buruh migran. Hal ini terbukti ketika seorang isteri yang telah pulang menjadi buruh migran memiliki posisi lebih superior daripada suami. Suami adalah subordinat dari isteri terutama dalam pengambilan keputusan yang berdampak pada kepentingan keluarga baik secara internal maupun eksternal. Isteri tidak lagi melihat bagaimana konstruk sosial tentang relasi suami dan isteri yang diberlakukan oleh lingkungan mereka dan yang sudah disepakati sebelum isteri berangkat menajdi buruh migran; (3) Suami tetap berpendapat bahwa secara sosial relasi yang harus dibentuk dalam keluarga adalah kedudukan suami lebih tinggi dari isteri. Meskipun pada kenyataannya, dalam konteks internal suami adalah subordinat dari isteri.

Balai Pustaka, 1997.

Hadari Nawawi, Metodologi Penelitian Bidang Sosial. Yogyakarta: Gajahmada University Press, 1995.

Husein Muhammad, Fiqh Perempuan, Refleksi Kyai atas Wacana Agama dan Gender, Yogyakarta: LkiS, 2009.

Moleong, Lexi, J., Metodologi Penelitian Kualitatif. Bandung: Rosdakarya, 2001.

Ch, Mufidah, Psikologi Keluarga Islam Berwawasan Gender, Malang: UINMalang Press, 2008.

Az Zuhaili, Wahbah bin Musthafa, Al Fiqh al Islami wa Adillatuhu li al Maktabah asy Syamilah, Damaskus: Daar al Fikr.

Az Zuhaili, Wahbah bin Musthafa, At Tafsir al Munir fi al 'Aqidah wa asy Syari'ah, Damaskus: Daar al Fikr, 1418 H. 